\title{
Early Emergence of Neural Activity in the Developing Mouse Enteric Nervous System
}

\author{
Marlene M. Hao, ${ }^{1}$ Werend Boesmans, ${ }^{3,4}$ Valentine Van den Abbeel, ${ }^{3}$ Ernest A. Jennings, ${ }^{1}$ Joel C. Bornstein, ${ }^{2}$ \\ Heather M. Young, ${ }^{1}$ and Pieter Vanden Berghe ${ }^{3}$ \\ Departments of ${ }^{1}$ Anatomy and Cell Biology and ${ }^{2}$ Physiology, the University of Melbourne, Parkville, Victoria 3010, Australia, ${ }^{3}$ Laboratory For Enteric \\ NeuroScience, Translational Research Center for Gastrointestinal Disorders, Katholieke Universiteit Leuven, 3000 Leuven, Belgium, and ${ }^{4}$ Division of \\ Molecular Neurobiology, MRC National Institute for Medical Research, London NW7 1AA, United Kingdom
}

Neurons of the enteric nervous system (ENS) arise from neural crest cells that migrate into and along the developing gastrointestinal tract. A subpopulation of these neural-crest derived cells express pan-neuronal markers early in development, shortly after they first enter the gut. However, it is unknown whether these early enteric “neurons" are electrically active. In this study we used live Ca ${ }^{2+}$ imaging to examine the activity of enteric neurons from mice at embryonic day 11.5 (E11.5), E12.5, E15.5, and E18.5 that were dissociated and cultured overnight. PGP9.5-immunoreactive neurons from E11.5 gut cultures responded to electrical field stimulation with fast $\left[\mathrm{Ca}^{2+}\right]_{\mathrm{i}}$ transients that were sensitive to TTX and $\omega$-conotoxin GVIA, suggesting roles for voltage-gated $\mathrm{Na}^{+}$channels and N-type voltage-gated $\mathrm{Ca}^{2+}$ channels. E11.5 neurons were also responsive to the nicotinic cholinergic agonist, dimethylphenylpiperazinium, and to ATP. In addition, spontaneous $\left[\mathrm{Ca}^{2+}\right]_{\mathrm{i}}$ transients were present. Similar responses were observed in neurons from older embryonic gut. Wholecell patch-clamp recordings performed on E12.5 enteric neurons after 2-10 h in culture revealed that these neurons fired both spontaneous and evoked action potentials. Together, our results show that enteric neurons exhibit mature forms of activity at early stages of ENS development. This is the first investigation to directly examine the presence of neural activity during enteric neuron development. Along with the spinal cord and hindbrain, the ENS appears to be one of the earliest parts of the nervous system to exhibit electrical activity.

\section{Introduction}

The enteric nervous system (ENS) is a large network of neurons and glia within the gastrointestinal tract wall that controls and regulates many functions, such as motility and secretion (Furness, 2006). The ENS arises from neural crest cells, mostly from the vagal region of the neural tube (Le Douarin and Teillet, 1973). In embryonic mice, neural crest-derived cells migrate into the developing foregut at embryonic day 9.5 (E9.5) and colonize the gastrointestinal tract in a rostral-to-caudal wave (Kapur et al., 1992; Anderson et al., 2006). A set of coordinated events is

Received June 15, 2011; revised Aug. 16, 2011; accepted Sept. 6, 2011.

Author contributions: M.M.H., J.C.B., H.M.Y., and P.V.B. designed research; M.M.H., W.B., V.V.d.A., and P.V.B. performed research; E.A.J. contributed unpublished reagents/analytic tools; M.M.H., V.V.d.A., and P.V.B. analyzed data; M.M.H., W.B., J.C.B., H.M.Y., and P.V.B. wrote the paper.

This work was supported by Research Foundation Flanders (Fonds Wetenschappelijk Onderzoek; FWO) Grant G.0501.10 (P.V.B.) and Australian Research Council Discovery Grant DP0878755 (H.M.Y., J.B.C.). M.M.H received a PORES (Postgraduate Overseas Research Experience) scholarship from the University of Melbourne. W.B. is a postdoctoral fellow of the FWO. We thank Vassilis Pachnis (National Institute for Medical Research, London, UK) for use of the Wnt-1-CRE/YFP mice, and the members of LENS (Laboratory For Enteric NeuroScience) for their discussions and expert help in preparing experiments.

The authors declare no competing financial interests.

Correspondence should be addressed to Dr. Pieter Vanden Berghe, Laboratory for Enteric NeuroScience (LENS), Translational Research Center for Gastrointestinal Disorders (TARGID), 0\&N 1, mailstop 701, Herestraat 49, 3000 Leuven, Belgium. E-mail: Pieter.VandenBerghe@med.kuleuven.be.

V. Van den Abbeel's present address: Interdisciplinary Research Center, Department of Physiology, KULeuven, Campus Kortrijk, 8500 Kortrijk, Belgium.

E. A. Jennings' present address: School of Medicine and Dentistry, James Cook University, Cairns QLD 4870, Australia.

DOI:10.1523/JNEUROSCI.3053-11.2011

Copyright $\odot 2011$ the authors $\quad 0270-6474 / 11 / 3115352-10 \$ 15.00 / 0$ required to produce the mature ENS from enteric neural crest-derived cells (ENCCs) including proliferation, migration, differentiation into neurons of various neurochemical phenotypes, formation of ganglia, development of neuronal activity, axon extension and pathfinding, and synaptogenesis. Defects at any stage of ENS development could result in severe pediatric motility problems (Young, 2008; Gershon, 2010), some of which can lead to irritable bowel syndrome in adulthood (Chitkara et al., 2008). The cellular and molecular mechanisms that influence the early events in ENS development, including proliferation and migration, are relatively well understood (Young and Newgreen, 2001; Young, 2008; Burns et al., 2009; Hao and Young, 2009; Laranjeira and Pachnis, 2009; Gershon, 2010). In contrast, little is known about the later events in ENS development, including axon pathfinding, dendrite formation, synaptogenesis and the appearance of neuronal activity.

Over 20 years ago, it was reported that a subpopulation of ENCCs starts to express a variety of pan-neuronal markers at E10.5, shortly after they first enter the gut (Baetge and Gershon, 1989). However, neurally mediated motility patterns are not present in the mouse intestine until E18.5 (Roberts et al., 2010). Thus, although some ENCCs start expressing neuronal markers from E10.5 onwards, there is currently no direct evidence that these "neurons" are electrically excitable and behave like mature neurons. In the developing CNS, electrical activity and neurotransmitter release are present during embryonic development and influence many aspects of neuron circuitry formation in partnership with genetic programs (Moody and Bosma, 2005; 
Spitzer, 2006; Ben-Ari, 2008; Ben-Ari and Spitzer, 2010). Similar mechanisms also operate within the developing ENS as inhibition of activity (Vohra et al., 2006; Hao et al., 2010) or genetic disruptions to neurotransmitter synthesis or uptake (Li et al., 2010, 2011) can perturb the migration and differentiation of ENCCs. However, several key questions remain unanswered: when do neurons in the embryonic gut become electrically active? Can they respond to electrical or chemical stimuli? Do they exhibit spontaneous activity?

In this study, we used calcium imaging and patch-clamp electrophysiology to examine the activity of ENCCs dissociated from mice of various embryonic ages that were cultured for up to $24 \mathrm{~h}$. We found that a subpopulation of ENCCs can fire action potentials via voltage-gated $\mathrm{Na}^{+}$channels, display spontaneous and evoked typical neuronal $\left[\mathrm{Ca}^{2+}\right]_{\mathrm{i}}$ transients and respond to neurotransmitters early in the development of the ENS.

\section{Materials and Methods}

Animals. For experiments using E12.5 and older ages, C57BL/6J mice were used. For studies using E11.5 mice, Wnt-1-CRE/YFP mice were used, where all neural crest-derived cells express YFP (Druckenbrod and Epstein, 2005; Cassiman et al., 2006). Pregnant females were killed by $\mathrm{CO}_{2}$ followed by cervical dislocation. The embryos were quickly removed and immediately decapitated before dissection, as approved by the Animal Ethics Committees of Katholieke Universiteit Leuven (KULeuven) and the University of Melbourne.

Tissue dissociation and short term culture. Embryos were dissected in sterile Krebs solution (in mM: $120.9 \mathrm{NaCl}, 5.9 \mathrm{KCl}, 1.2 \mathrm{MgCl}_{2}, 2.5 \mathrm{CaCl}_{2}$, $1.2 \mathrm{NaH}_{2} \mathrm{PO}_{4}, 14.4 \mathrm{NaHCO}_{3}, 11.5$ glucose). The gut was removed and dissociated in collagenase II $(338 \mathrm{U} / \mathrm{ml}$; Worthington Biochemical Corp.) for $15-20 \mathrm{~min}$ at $37^{\circ} \mathrm{C}$ followed by gentle pipetting. Cells were plated on glass coverslips in culture media (DMEM/F12 supplemented with 10\% FBS, $200 \mathrm{~mm}$ L-glutamine, $100 \mathrm{U}$ penicillin/streptomycin) overnight. At E11.5, the entire gut caudal to the stomach was dissected from heterozygous Wnt-1-CRE/YFP embryos. At E12.5, only the small intestine was prepared for culture. At E15.5 and E18.5, the duodenum (rostral 1/3 of the small intestine) and colon (including cecum) were cultured separately to compare the behavior of neurons in different gut regions. For adult small intestine, the external muscle layers were peeled away from the submucosa and mucosa and then mechanically broken up using a scalpel. The external muscle, containing the myenteric plexus, was dissociated using collagenase II with protease (10 mg/ml; Sigma) and albumin $(50 \mathrm{mg} / \mathrm{ml}$; Serva Electrophoresis) and plated on coverslips in the same culture media as embryonic preparations. All cells were cultured overnight at $37^{\circ} \mathrm{C}\left(5 \% \mathrm{CO}_{2}\right)$ before $\mathrm{Ca}^{2+}$ imaging.

Calcium imaging. Changes in intracellular $\mathrm{Ca}^{2+}$ concentration $\left(\left[\mathrm{Ca}^{2+}\right]_{\mathrm{i}}\right)$ were assayed by Fluo-4 imaging as described previously (Vanden Berghe et al., 2008; Boesmans et al., 2009; Gomes et al., 2009). Cells were loaded with Fluo-4AM ( $5 \mu \mathrm{M}$; Invitrogen) in HEPES solution (in mM: $148 \mathrm{NaCl}$, $5 \mathrm{KCl}, 1 \mathrm{MgCl}_{2}, 2 \mathrm{CaCl}_{2}, 10$ glucose, 10 HEPES, with $\mathrm{pH}$ adjusted to 7.4 using $\mathrm{NaOH}$ ) for $20 \mathrm{~min}$, and then rinsed for $20 \mathrm{~min}$ with fresh solution before recording. Coverslips were then transferred to a recording chamber and mounted on a Zeiss Axiovert 200M microscope equipped with a monochromator (Poly V) and a cooled CCD camera (Imago QE), both from TILL Photonics. Fluo- 4 was excited at $475 \mathrm{~nm}$, and its fluorescence emission was collected at $525 \mathrm{~nm}$ using $20 \times$ or $40 \times$ objectives. Images were collected using TILLVISION software (TILL Photonics) and analysis was performed using custom written macros in IGOR PRO (Wavemetrics). ROIs were drawn over each cell, and fluorescence intensity was calculated and normalized per ROI to its baseline starting value. All recordings were performed at room temperature except for spontaneous activity experiments, which were performed at $37^{\circ} \mathrm{C}$. Changes in fluorescence intensity were calculated and expressed as a fraction of the baseline fluorescence, as $F_{\mathrm{i}} / F_{0}$. Peaks in $\left[\mathrm{Ca}^{2+}\right]_{\mathrm{i}}$ were individually determined, with a minimum increase of 5 times the intrinsic noise level. The amplitude of the $\left[\mathrm{Ca}^{2+}\right]_{\mathrm{i}}$ peak was calculated as the maximum increase in $\left[\mathrm{Ca}^{2+}\right]_{\mathrm{i}}$ above baseline (Fig. 1). Amplitudes of $\left[\mathrm{Ca}^{2+}\right]_{\mathrm{i}}$ peaks in E11.5 cells were first corrected for their additional YFP background fluorescence. Activity over Time (AoT) images, in which only responding cells are shown, were generated by an automated routine that attributes, on a pixel by pixel basis, the maximum value of that pixel in a certain period of time. The value was only assigned if a significant change was observed; otherwise the pixel in the AoT image was set to 0 . Thus all fluorescent information that did not change in a given period of time was filtered out.

Electrical field stimulation. Electrical field stimulation (EFS) was applied as a train of $400 \mu$ s pulses at $20 \mathrm{~mA}$ at $20 \mathrm{~Hz}$ for $2 \mathrm{~s}$ using a WPI A385 stimulator through 2 parallel $\mathrm{Pt} / \mathrm{Ir}$ wires ( $1 \mathrm{~mm}$ spacing).

Pharmacological agents. $\mathrm{Ca}^{2+}$-free HEPES was made with the same components as normal HEPES but $\mathrm{CaCl}_{2}$ was replaced with $\mathrm{MgCl}_{2}(2.5$ $\mathrm{mM}$ ), and EDTA (2 mM) was added. The following drugs were added to the HEPES bath solution to block specific channels: TTX ( $1 \mu \mathrm{M}$; Sigma), $\omega$-conotoxin-GVIA ( $1 \mu \mathrm{M}$; Alomone Labs), nicardipine ( $1 \mu \mathrm{M}$; Sigma), $\omega$-Agatoxin (0.1 $\mu \mathrm{M}$; Sigma), SNX-482 (0.1 $\mu \mathrm{M}$; Alomone Labs), and nickel $\left(\mathrm{Ni}^{2+}, 50 \mu \mathrm{M}\right.$; Merck). Recordings (including controls) were performed without constant perfusion to maintain bath volume. The following agonists were applied locally onto cells for $10 \mathrm{~s}$, under constant local perfusion: dimethylphenylpiperazinium (DMPP; $1 \mu \mathrm{M}$; Fluka); ATP (10 $\mu \mathrm{M}$; Sigma), serotonin (5-HT; $1 \mu \mathrm{M}$; Sigma), substance P (1 $\mu \mathrm{M}$; UCB Bioproducts), and CGRP (0.1 $\mu \mathrm{M}$; Sigma).

Immunohistochemistry. After recording, cells were fixed in $4 \%$ paraformaldehyde (in HEPES) for $30 \mathrm{~min}$ at room temperature and processed for immunohistochemistry as described previously (Boesmans et al., 2008). Briefly, cells were permeabilized with $0.5 \%$ Triton X-100 in PBS containing $4 \%$ donkey serum, and incubated in the following primary antibodies for $24 \mathrm{~h}$ at $4^{\circ} \mathrm{C}$ : mouse anti-PGP9.5 (1:500; Ultraclone); goat anti-GFP (1:200; Abcam) for E11.5 Wnt-1-CRE/YFP preparations; mouse anti-neuronal class III $\beta$-tubulin (Tuj1, 1:2000; Covance); rabbit anti-synaptophysin (1:1000; DAKO). After washing, secondary antibodies were applied for $2 \mathrm{~h}$ at room temperature: donkey anti-mouse Alexa 594 (1:1000; Invitrogen); donkey anti-goat Alexa 488 (1:1000; Invitrogen); donkey anti-rabbit FITC (1:200; Jackson Laboratories). Preparations were imaged using the same Zeiss Axiovert 200M microscope equipped with a monochromator and CCD camera as described above, using appropriate filter cubes (Gomes et al., 2009). Synaptophysin immunohistochemistry was imaged using a Zeiss Pascal confocal laser scanning microscope.

Whole-cell patch-clamp electrophysiology. Electrophysiology was performed on dissociated cells from E12.5 small intestine within 2-10 h of culture. Cells were visualized on a Zeiss Axiovert 25 microscope using bright-field optics and perfused in HEPES-buffered saline for recording (in mM: $140 \mathrm{NaCl}, 5 \mathrm{KCl}, 10 \mathrm{HEPES}, 2 \mathrm{CaCl}_{2}, 2 \mathrm{MgCl}_{2}$, and D-glucose, adjusted to $\mathrm{pH}=7.4$ using $\mathrm{NaOH}$ ). Patch pipettes were pulled from borosilicate glass capillaries (Harvard Apparatus) and filled with a potassium methanesulfonate internal solution adapted from Mao et al. (2006) (in mm: $115 \mathrm{KMeSO}_{3}, 9 \mathrm{NaCl}, 10$ HEPES, $0.1 \mathrm{CaCl}_{2}, 1$ $\mathrm{MgCl}_{2}, 0.2$ BAPTA. $\mathrm{K}_{4}, 2 \mathrm{Mg}$-ATP and $0.25 \mathrm{Na}-\mathrm{GTP}$ ). All recordings were made at $33^{\circ} \mathrm{C}$ using an Axopatch 200B amplifier, and pCLAMP9 software (both from Molecular Devices). Data were captured at $50 \mathrm{kHz}$ and filtered at $2 \mathrm{kHz}$. To minimize errors in current clamp, high resistance pipettes were pulled $(\sim 10 \mathrm{M} \Omega)$ and recordings were made in "fast I-clamp" mode (Magistrettri et al., 1996). Liquid junction potentials were calculated using JPCalcW (Molecular Devices) and corrected offline. Measurements of action potential properties were made using Clampfit (Molecular Devices). Spontaneous activity was recorded in the absence of any injected current. To evoke action potentials, membrane potential was held between -60 and $-70 \mathrm{mV}$, and cells depolarized with a short (1 ms) current pulse.

Data presentation and statistical analysis. All data, including graphs, are presented as mean \pm SEM. " $n$ " refers to the number of cells, and " $N$ " refers to the number of coverslips examined. A minimum of two experiments on different days using different litters of mice was performed for each experimental condition. Unless otherwise stated, differences in means were analyzed using one-way ANOVAs followed by Bonferroni post hoc test. Differences were considered to be significant if $p<0.05$. Statistical analyses were performed with Microsoft Excel, GraphPad, or Minitab. 

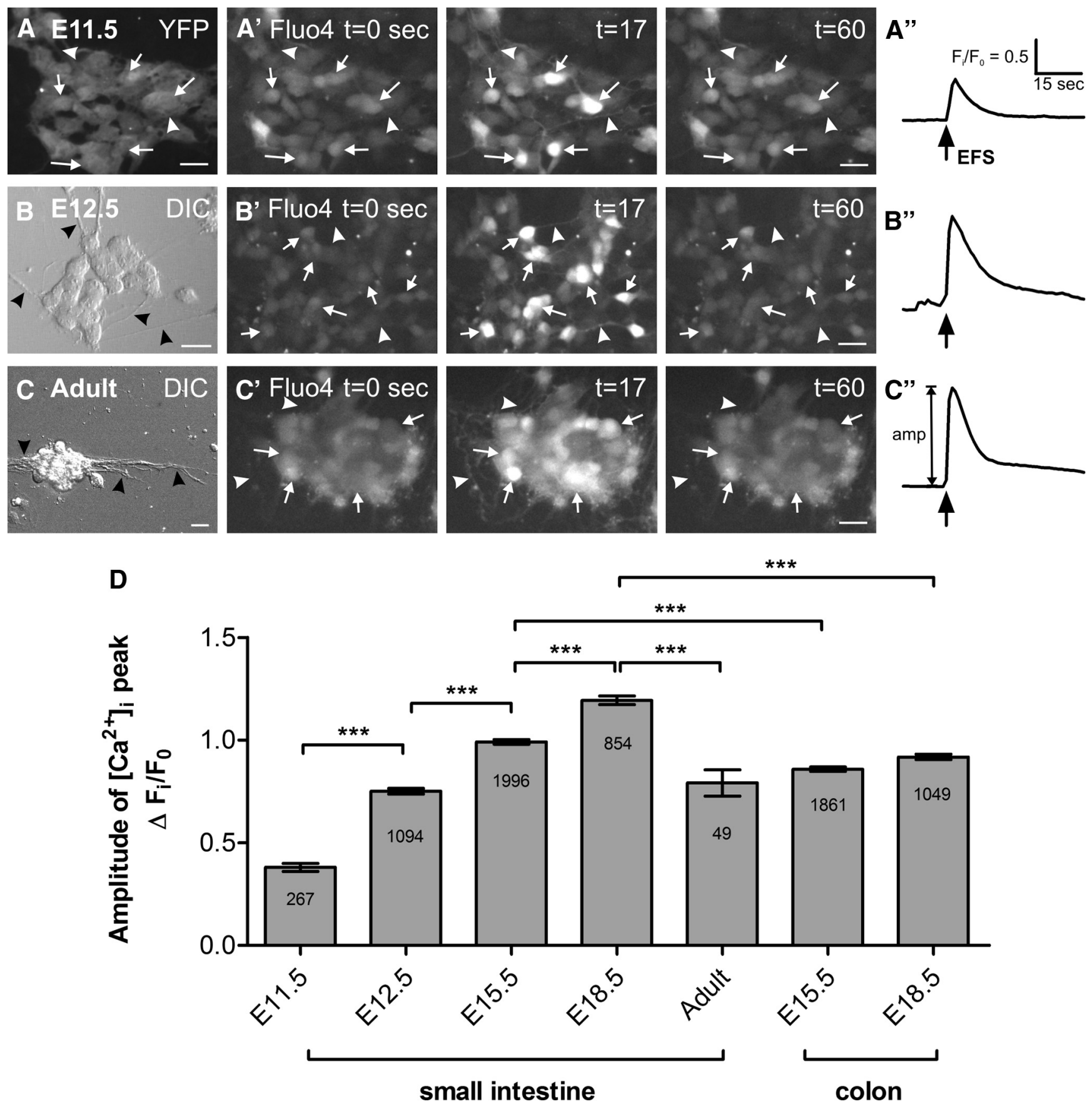

Figure 1. EFS-evoked $\left[\mathrm{Ca}^{2+}\right]_{\mathrm{i}}$ transients. Representative fluorescence micrographs of the $\left[\mathrm{Ca}^{2+}\right]_{\mathrm{i}}$ response in dissociated neurons from E11.5 mid-and hindgut $(\boldsymbol{A}), \mathrm{E} 12.5 \mathrm{small}$ intestine $(\boldsymbol{B})$ and adult small intestine $(\boldsymbol{C})$ loaded with Fluo-4. The dissociation yielded small clumps of cells as well as single cells. ENCCs in E11.5 were YFP ${ }^{+}(\boldsymbol{A})$, while neurons from E12.5 $(\boldsymbol{B})$ and adult $(\boldsymbol{C})$ preparations were round and had extended neurites (black arrowheads). EFS was applied to cells at $t=15 \mathrm{~s}$ for $2 \mathrm{~s}$ and the Fluo-4 signal increased sharply (arrows) at $t=17$. Neurites were also responsive (arrowheads). Scale bars, $20 \mu \mathrm{m} . A^{\prime \prime}-C^{\prime \prime}$, Representative traces of the EFS-induced $\left[\mathrm{Ca}^{2+}\right]_{\mathrm{i}}$ transient at each age (same scale for all). The amplitude of each transient was calculated from the baseline $F_{\mathrm{i}} / F_{0}$ value to the maximum $F_{\mathrm{i}} / F_{0}$ at the peak. $\boldsymbol{D}$, Amplitude of the EFS-evoked $\left[\mathrm{Ca}^{2+}\right]_{\mathrm{i}}$ transients from preparations of different age groups and gut regions (mean \pm SEM). Significant increases were observed between almost all populations of cells from E11.5 to E18.5 $(* * *<0.0001 ; n=$ numbers of cells shown). Post hoc correction for the background YFP signal was made for the calculation of E11.5 $\left[\mathrm{Ca}^{2+}\right]_{\mathrm{i}}$ transient amplitude (an uncorrected transient is shown in $\boldsymbol{A}^{\prime \prime}$ ).

\section{Results}

Identification of neurons in primary culture using live $\mathrm{Ca}^{2+}$-imaging and PGP9.5 immunocytochemistry

We examined the $\left[\mathrm{Ca}^{2+}\right]_{\mathrm{i}}$ activity of ENCCs in dissociated gut from E11.5, E12.5, E15.5, E18.5 and adult mice in overnight primary cultures. E11.5 cultures were established using Wnt-1$\mathrm{CRE} / \mathrm{YFP}$ mice, as in these mice all ENCCs, including the subpopulation that expresses pan-neuronal markers, express
YFP (Fig. 1A). Enteric neurons in preparations from E12.5 and older embryos could be identified by their distinctive morphology as they had round cell bodies that were clustered in small groups, from which neurites projected (Fig. $1 B, C$ ); the vast majority of cells with these morphological features was PGP9.5immunoreactive (Fig. 2A). As it was not necessary to rely on the Wnt-1-CRE/YFP reporter signal to identify neurons in E12.5 and older mice, wild-type embryos were used for these ages. Live 

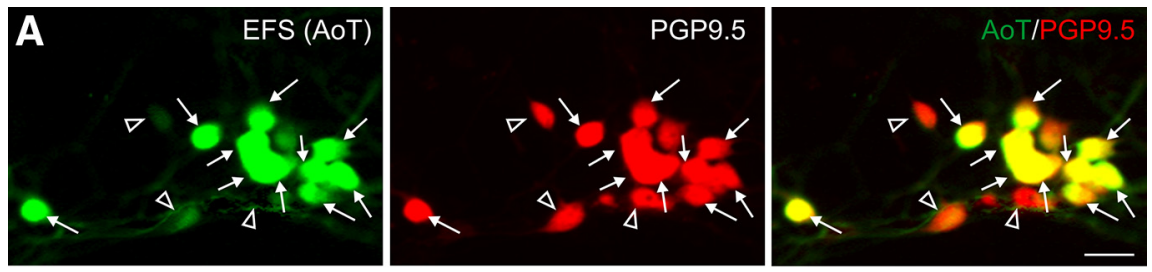

B

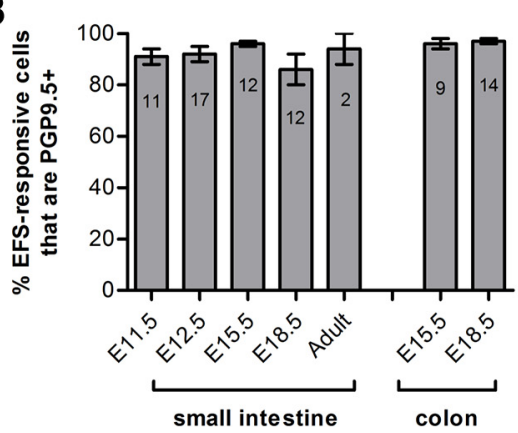

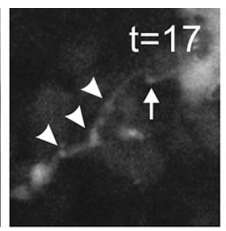
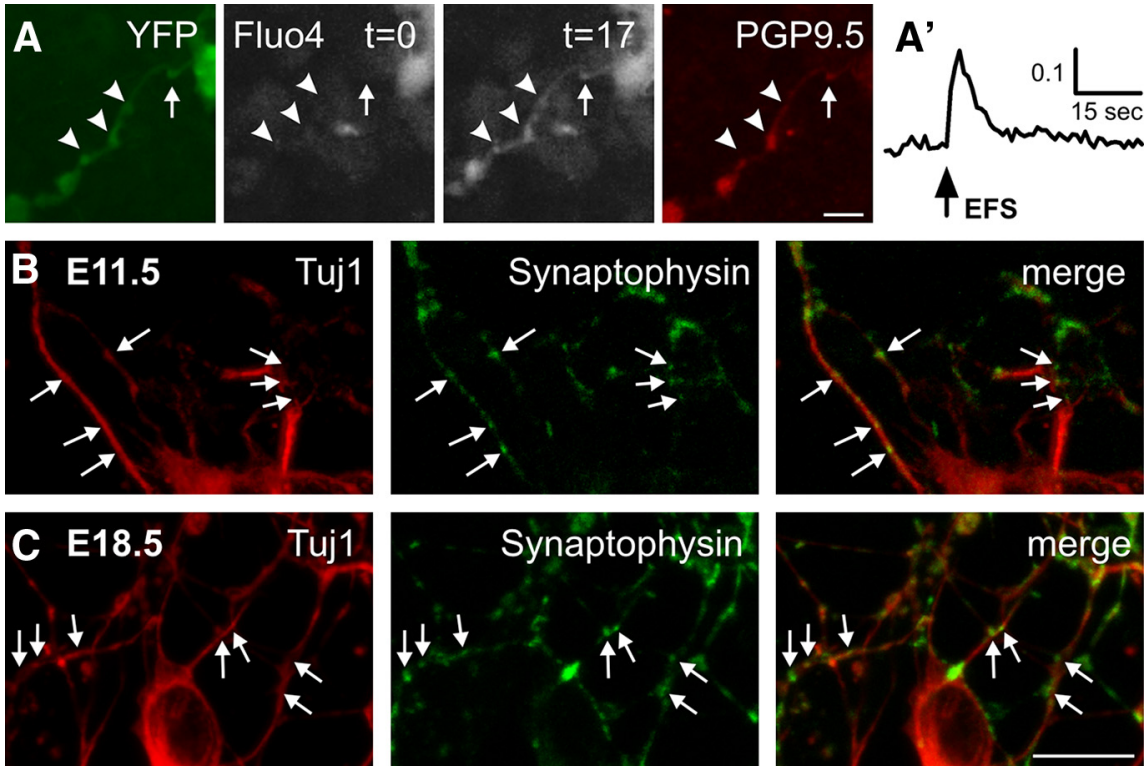

Figure 3. Response of neurites. $A$, EFS-induced $\left[\mathrm{Ca}^{2+}\right]_{\mathrm{i}}$ activity in E11.5 $\mathrm{YFP}{ }^{+}$neurites, with varicosities (arrowheads). $\mathrm{Ca}^{2+}$ concentration is low at $t=0$, then increases sharply at $t=17$ in response to EFS (not corrected for YFP fluorescence). Neurites were PGP9.5-immunoreactive. Scale bar, $20 \mu \mathrm{m}$. $\boldsymbol{A}^{\prime}$, Trace of the change in $\left[\mathrm{Ca}^{2+}\right]_{i}$ at the position of the arrow. $\boldsymbol{B}, \boldsymbol{C}$, Fluorescence micrograph of synaptophysin immunoreactivity in E11.5 $(\boldsymbol{B})$ and E18.5 duodenum $(\boldsymbol{C})$ cultures. Weak punctate staining (arrows) was observed along Tuj1-immunoreactive neurites at E11.5. At E18.5, synaptophysin-immunoreactive varicosities were more numerous and showed more intense immunostaining. Scale bar, $10 \mu \mathrm{m}$.

$\mathrm{Ca}^{2+}$ recordings were made from fields of view containing cells with this neuron-like morphology.

EFS induced a sharp increase in $\left[\mathrm{Ca}^{2+}\right]_{\mathrm{i}}$ with a slower exponential decay in neurons from cultured adult small intestine (Fig. 1C). A similar $\left[\mathrm{Ca}^{2+}\right]_{i}$ response was elicited in cells with neuron-like morphology from cultures of E12.5-E18.5 gut (Fig. $1 B$ ), and in $14 \pm 2 \%$ of $\mathrm{YFP}^{+}$cells from E11.5 gut $(n=1505,8$ experiments; Fig. $1 A$; see Notes). The amplitude of the EFS-induced $\left[\mathrm{Ca}^{2+}\right]_{\mathrm{i}}$ transients increased from E11.5 to E18.5 (Fig. 1D). In the small intestine, significant stepwise increases were observed between each age group. In the colon, $\left[\mathrm{Ca}^{2+}\right]_{\mathrm{i}}$ transients were significantly smaller than those from the duodenum at the same embryonic age. Interestingly, although the average $\left[\mathrm{Ca}^{2+}\right]_{\mathrm{i}}$ transient amplitude in cells derived from E15.5 colon is higher than those from E12.5 small intestine $(p<0.0001)$, the response in cells from E18.5 colon is lower than that of E15.5 duodenum cells $(p<0.001)$. In addition, the $\left[\mathrm{Ca}^{2+}\right]_{\mathrm{i}}$ transients in neurons from the adult small intestine were smaller than those in neurons from E18.5. This may be an artifact as adult neurons did not appear as robust and recovered more slowly following dissociation than embryonic cells.

Following EFS, cells were fixed and processed for immunohistochemistry using an antiserum against the panneuronal marker, PGP9.5. At all ages examined, $\sim 90 \%$ of cells that showed EFS-induced $\left[\mathrm{Ca}^{2+}\right]_{\mathrm{i}}$ transients were also PGP9.5 ${ }^{+}$(Fig. 2A,B). However, not all PGP9. $5^{+}$cells were responsive to EFS. At E11.5, $\sim 40 \%$ of PGP9. $5^{+}$cells showed EFS-induced $\left[\mathrm{Ca}^{2+}\right]_{\mathrm{i}}$ activity. This increased significantly in preparations from E15.5 and E18.5 small intestine (Fig. 2C).

$\mathrm{YFP}^{+}$neurites, which showed PGP9.5 immunostaining after fixation, were present in many E1 1.5 preparations (Fig. 3A). Punctate synaptophysin immunoreactivity was also present along Tuj1-immunoreactive neurites in E11.5 preparations (Fig. 3B). In response to $\mathrm{EFS}, \mathrm{YFP}^{+}$neurites showed changes in $\left[\mathrm{Ca}^{2+}\right]_{\mathrm{i}}$ along their entire length, with more noticeable changes in their varicosities (Fig. $3 A, A^{\prime}$ ). EFS-responsive neurites were also present in preparations from older embryos (Fig. 1B,C). The change in $\left[\mathrm{Ca}^{2+}\right]_{\mathrm{i}}$ was greater than that observed in E11.5 neurites, and synaptophysin immunoreactivity was more intense (Fig. 3C).

\section{Effects of blocking voltage-gated $\mathrm{Na}^{+}$ channels on} EFS-evoked $\left[\mathrm{Ca}^{2+}\right]_{\mathrm{i}}$ transients

To examine the role of voltage-gated sodium channels, EFS was applied twice to each preparation: the first time in normal bath solution; cells were then bathed in solution containing TTX $(1 \mu \mathrm{M})$ for 2 min, and a second EFS applied. Timed control experiments were also conducted where a second EFS was performed in the absence of TTX. TTX reduced the $\left[\mathrm{Ca}^{2+}\right]_{\mathrm{i}}$ response to EFS in every preparation, either by completely eliminating the $\left[\mathrm{Ca}^{2+}\right]_{\mathrm{i}}$ transient or by reducing the amplitude of the $\left[\mathrm{Ca}^{2+}\right]_{\mathrm{i}}$ peaks (Fig. $4 A$ ). TTX eliminated the EFS-induced $\left[\mathrm{Ca}^{2+}\right]_{i}$ transient in the majority of neurons at all embryonic ages and in both gut regions (Fig. $4 B$ ).

For neurons in which a response to EFS was still detectable in the presence of TTX, the change in the amplitude of the $\left[\mathrm{Ca}^{2+}\right]_{\mathrm{i}}$ 

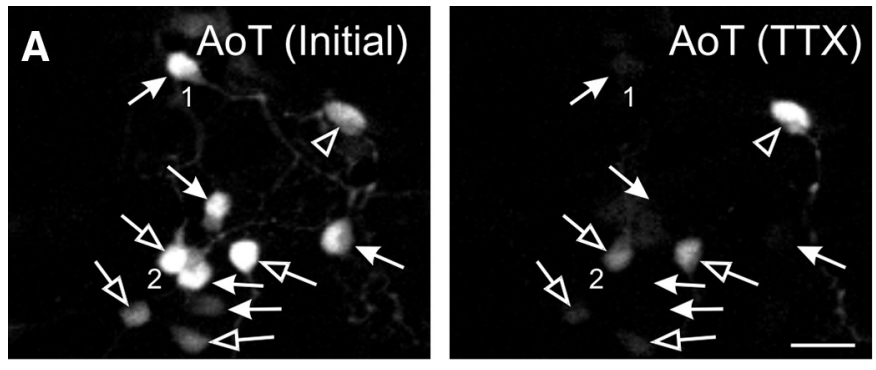

$A^{\prime}$
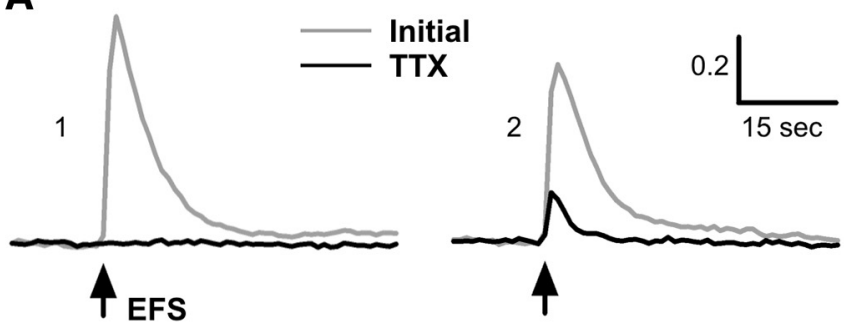

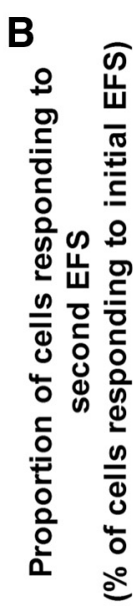

E12.5 small intestine
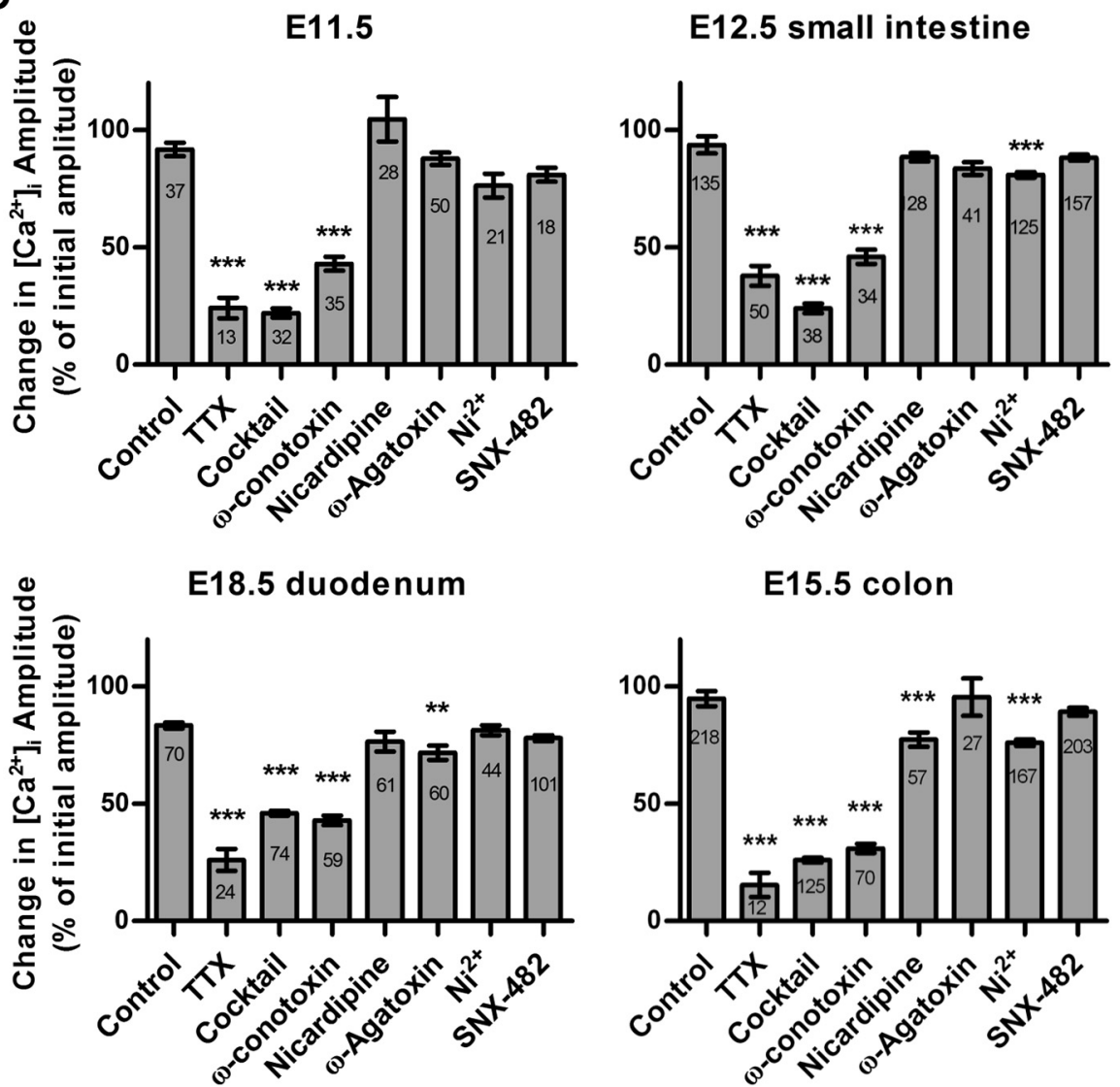

E15.5 duodenum

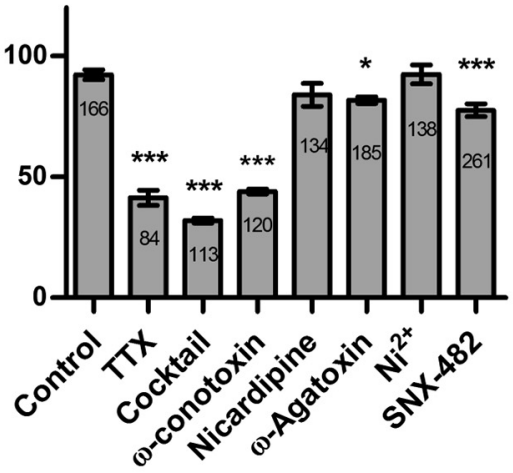

E18.5 colon

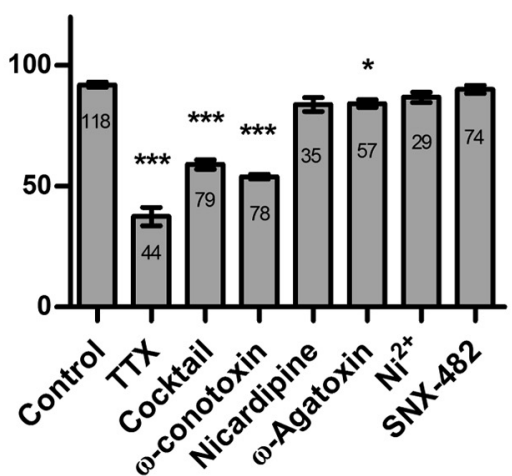

Figure 4. Effects of antagonists of voltage-gated ion channels. A, AOT images of the EFS response in the same cells upon an initial stimulation (left), and in the presence of TTX (right). TTX completely abolished the EFS response in $\sim 50 \%$ of neurons (closed arrows, cell 1). Cells that had a TTX-resistant response, showed a reduced [Ca $\left.{ }^{2+}\right]_{i}$ peak amplitude (open arrows, cell 2). In very few cells, the $\left[\mathrm{Ca}^{2+}\right]_{\mathrm{i}}$ response was not affected by TTX (open arrowhead). Scale bar, $20 \mu \mathrm{m}$. $\boldsymbol{A}^{\prime}$, Typical traces of responses from cells in $\boldsymbol{A}: 1$, there is no detectable change in $F_{\mathrm{i}} / F_{0}$ upon EFS stimulation at $t=15 \mathrm{~s} ; 2$, the amplitude of the $\left[\mathrm{Ca}^{2+}\right]_{\mathrm{i}}$ response is reduced. $\boldsymbol{B}$, Proportion of cells (mean \pm SEM) responding to an initial EFS after TTX application. The proportion was significantly reduced at all ages [**p $<0.0001 ; N=$ number of coverslips shown, Control: $n=39$ (E11.5), $n=146$ (E12.5), $n=171$ (E15.5 small intestine), $n=75$ (E18.5 small intestine), $n=6$ (adult), $n=$ 228 (E15.5 colon), $n=118$ (E18.5 colon); TTX: $n=50$ (E11.5), $n=94$ (E12.5), $n=144$ (E15.5 small intestine), $n=91$ (E18.5 small intestine), $n=6$ (adult), $n=45$ (E15.5 colon), $n=111$ (E18.5 colon)]. C, Antagonist-induced changes in amplitude of the EFS-evoked $\left[\mathrm{Ca}^{2+}\right]_{\mathrm{i}}$ transient (mean \pm SEM, calculated as proportions of the initial amplitude). TTX, the VGCC antagonist cocktail, and $\omega$-conotoxin significantly reduced $\left[\mathrm{Ca}^{2+}\right]_{\mathrm{i}}$ peak amplitude at all ages examined. Other antagonists produced significant reductions at various ages and gut regions $\left({ }^{* * *} p<0.0001 ;{ }^{* *} p<0.001 ;\right.$ ${ }^{*} p<0.05, n=$ number of cells for each condition shown). 
transient was calculated as a percentage of the amplitude of their initial EFS response. The amplitudes of the $\left[\mathrm{Ca}^{2+}\right]_{i}$ peaks were significantly reduced to $\leq 40 \%$ of the initial peak at all ages (Fig. 4C).

\section{Role of extracellular calcium and effects of blockers of voltage-gated $\mathrm{Ca}^{2+}$ channels in EFS-evoked $\left[\mathrm{Ca}^{2+}\right]_{i}$ transients}

To determine whether EFS-evoked $\left[\mathrm{Ca}^{2+}\right]_{\mathrm{i}}$ transients required influx of extracellular calcium, experiments were performed in $\mathrm{Ca}^{2+}$-free bath solution and EDTA (2 mM). Removal of extracellular $\mathrm{Ca}^{2+}$ abolished all EFS-induced calcium transients at all ages and regions (data not shown). Following washout of the $\mathrm{Ca}^{2+}$-free solution, almost all $\left[\mathrm{Ca}^{2+}\right]_{\mathrm{i}}$ responses were restored. These data show that $\left[\mathrm{Ca}^{2+}\right]_{\mathrm{i}}$ transients evoked by EFS are, at least for their initiation, completely dependent on the influx of extracellular $\mathrm{Ca}^{2+}$ ions.

The roles of voltage-gated $\mathrm{Ca}^{2+}$ channels (VGCCs) were then examined using $\omega$-conotoxin GVIA to block $\mathrm{N}$-type $\mathrm{Ca}^{2+}$ channels, nicardipine to block L-type channels, $\omega$-Agatoxin to block P/Q-type channels, SNX-482 to block R-type channels, and $\mathrm{Ni}^{2+}$ to block both R- and T-type channels. In addition, a cocktail of these 5 antagonists was applied. None of the antagonists, individually or in combination, eliminated the EFS response. However, significant reductions to the amplitude of the EFS-evoked $\left[\mathrm{Ca}^{2+}\right]_{\mathrm{i}}$ transients were produced (Fig. $4 \mathrm{C}$ ). $\omega$-Conotoxin triggered a large reduction $(>50 \%)$ in the $\left[\mathrm{Ca}^{2+}\right]_{\mathrm{i}}$ peak at all ages (Fig. 4C). Nicardipine produced a small, but significant, reduction in E15.5 colon cultures. $\omega$-Agatoxin had a significant effect on cultures from E15.5 and E18.5 duodenum as well as E18.5 colon. SNX-482 only produced a significant effect on E15.5 duodenum, whereas $\mathrm{Ni}^{2+}$ reduced the transients in E12.5 small intestine as well as E15.5 colon cultures. Because $\mathrm{Ni}^{2+}$ at $50 \mu \mathrm{M}$ blocks R-type as well as T-type $\mathrm{Ca}^{2+}$ channels (Eliot and Johnston, 1994; Bian et al., 2004), we examined the effects of SNX-482 and $\mathrm{Ni}^{2+}$ consecutively on the same cells. In both E12.5 small intestine and E15.5 colon preparations, the change in the $\left[\mathrm{Ca}^{2+}\right]_{\mathrm{i}}$ peak in the presence of $\mathrm{Ni}^{2+}$ was significantly greater than in the presence of SNX-482 $(p<0.05$, Student's $t$ test, paired sample for means; $n=125$ and $n=115$ respectively), suggesting that T-type $\mathrm{Ca}^{2+}$ channels are involved at both ages. At E18.5, in both the duodenum and colon, TTX reduced the EFS-induced $\left[\mathrm{Ca}^{2+}\right]_{\mathrm{i}}$ transient to a significantly greater extent than the VGCC antagonists mixture, which suggests the involvement of other $\mathrm{Ca}^{2+}$ permeable channels.

\section{Responses to neurotransmitter receptor agonists}

There are many different neurotransmitters in the mature ENS (Galligan, 2002; Bornstein et al., 2004). We examined the response to the following agonists (applied for $10 \mathrm{~s}$ under constant perfusion): DMPP (1 $\mu \mathrm{M}$, to stimulate nicotinic receptors), ATP $(10 \mu \mathrm{M}), 5$-HT $(1 \mu \mathrm{M})$, substance P $(1 \mu \mathrm{M})$, or CGRP $(0.1 \mu \mathrm{M})$. EFS was first applied to identify neurons. The proportion of EFSresponsive neurons that also responded to drug application was determined. The majority of EFS-responsive neurons also responded to DMPP and ATP at all embryonic ages, including neurons from E11.5 cultures (Fig. $5 A, B$ ). Interestingly, the amplitude of the $\left[\mathrm{Ca}^{2+}\right]_{i}$ response to DMPP decreased in E18.5 neurons, both in the small intestine and colon (Fig. 5A). Almost all neurons responded to ATP at E11.5, 12.5, E15.5 and E18.5 (Fig. 5B). Very few cells responded to 5-HT at E11.5 and E12.5, and the proportion of neurons responding to $5-\mathrm{HT}$ was highest in E15.5 small intestine (Fig. 5C). Neurons rarely responded to
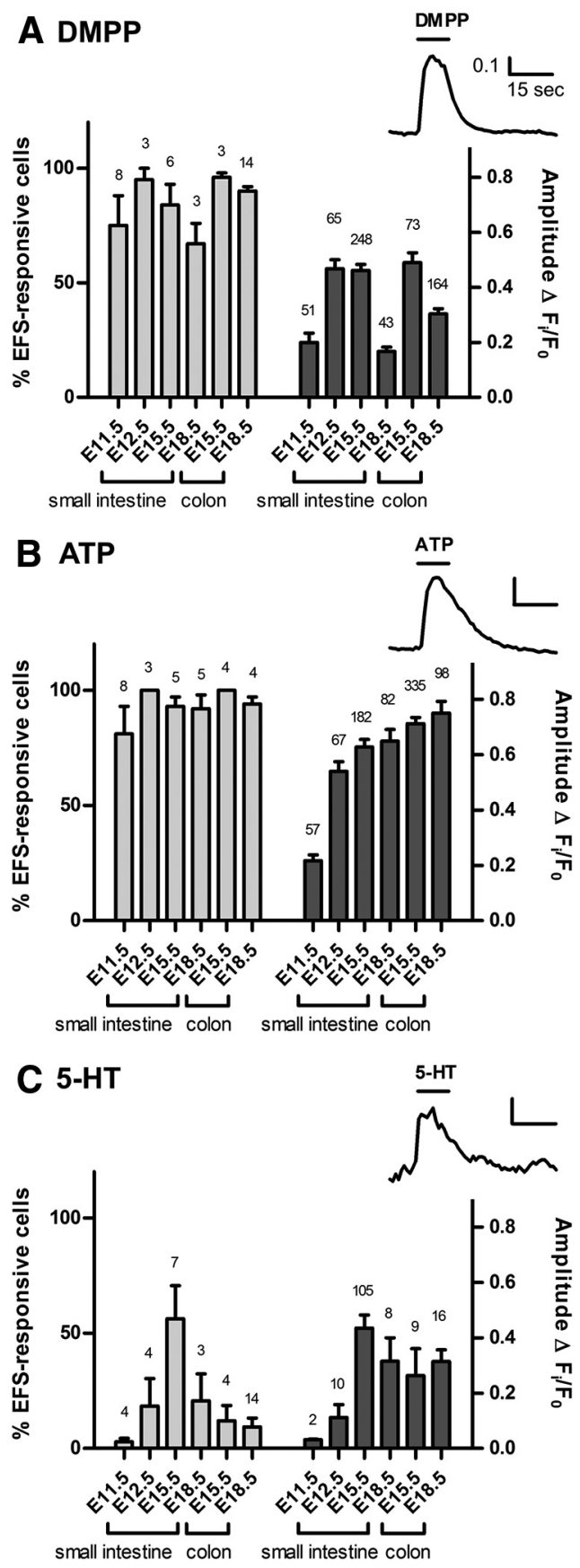

Figure 5. Responses to neurotransmitters and receptor agonists. $A-C$, Cells were first stimulated with EFS to identify neurons, and then exposed to DMPP $(\boldsymbol{A})$, ATP $(\boldsymbol{B})$, or 5 -HT (C). Insets show typical traces of the $F_{\mathrm{i}} / F_{0}$ responses. The proportion of EFS-responsive cells (mean $\pm \mathrm{SEM}$ ) that responded to each agonist is plotted on the left axis ( $N=$ number of coverslips shown). Right axis plots the amplitude of the agonist-evoked $\left[\mathrm{Ca}^{2+}\right]_{i}$ peak $(n=$ number of cells responding to each agonist are shown).

CGRP, except in the E18.5 small intestine, where responses were observed in 12 neurons ( of 15) on 1 coverslip only from a total of 7 coverslips examined. Less than $5 \%$ of cells responded to substance $\mathrm{P}$ at all embryonic ages, and with very small changes in $\left[\mathrm{Ca}^{2+}\right]_{\mathrm{i}}$ (data not shown). The amplitude of the $\left[\mathrm{Ca}^{2+}\right]_{\mathrm{i}}$ peak induced by each agonist showed some differences at different ages (Fig. 5). However, there was no obvious correlation between amplitude and age. 
Spontaneous $\left[\mathrm{Ca}^{2+}\right]_{\mathrm{i}}$ transients

Our results showed that sharp $\left[\mathrm{Ca}^{2+}\right]_{\mathrm{i}}$ increases in developing enteric neurons can be elicited electrically or by several neurotransmitter receptor agonists. We also investigated whether ENCC from E11.5 preparations showed spontaneous calcium transients; $10 \pm 3 \%$ of $\mathrm{YFP}^{+}$cells exhibited spontaneous activity $(N=10$ coverslips, $n=579 \mathrm{YFP}^{+}$cells; 4 experiments; Fig. 6). Post hoc immunohistochemistry revealed that only $15 \%$ of PGP9.5-immunoreactive cells $(n=94)$ in these preparations were spontaneously active (Fig. $6 A, C$ ). Some $\mathrm{YFP}^{+}$cells that did not show PGP9.5 immunostaining also showed spontaneous activity (Fig. $6 A, D)$. The frequency of firing was determined for each cell within the 2 min recording. The frequency distribution function was not significantly different between PGP9.5-positive and PGP9.5negative ENCCs, with $~ 50 \%$ of each cell type firing at $0.5-1 \mathrm{~Hz}$ (Fig. $6 B ; p>0.05$, two-sample Kolmogorov-Smirnov test).

\section{Action potentials at E12.5}

Preliminary whole-cell patch-clamp recordings were made from dissociated, 2-10 h cultures of E12.5 small intestine. Spontaneous and evoked action potentials were recorded from E12.5 neurons ( $n=28$ cells; Fig. 7 ). Cells had a resting membrane potential of $-53 \pm 3 \mathrm{mV}$. The input resistance was very high $(4 \pm 0.4 \mathrm{G} \Omega$ ) and cells were very small, with capacitances of $5.6 \pm 0.3 \mathrm{pF}$. Spontaneous action potentials were recorded from 2 neurons at resting membrane potential (Fig. 7A). The amplitude of evoked action potentials was $72 \pm 3 \mathrm{mV}$ and the durations at halfamplitude were $2.9 \pm 0.4 \mathrm{~ms}$ (Fig. $7 B$ ). On average, $103 \pm 11 \mathrm{pA}$ of current was required to generate an action potential.

\section{Discussion}

It has been known for over 20 years that very shortly after first entering the gut at E10.5, a subpopulation of ENCCs starts expressing pan-neuronal markers (Baetge and Gershon, 1989; Young et al., 1999). One question that has remained unanswered thus far is whether these early enteric neurons are electrically active. We performed calcium imaging and patch-clamp recording on short-term cultures (4-24 h) of embryonic enteric neurons and showed that they exhibited spontaneous activity, and were responsive to electrical stimulation and neurotransmitter receptor agonists. Thus, while the neural circuitry mediating propagating intestinal motility patterns is not functional until just before birth (Roberts et al., 2010), electrical activity occurs early in enteric neuron development.

Spontaneous $\left[\mathrm{Ca}^{2+}\right]_{\mathrm{i}}$ spikes have been observed in many parts of the developing nervous system and control essential aspects of development (Ben-Ari et al., 1989; Holliday and Spitzer, 1990; Gu and Spitzer, 1995; Wong et al., 1995; Milner and Landmesser, 1999; Gust et al., 2003). In our E11.5 cultures, subpopulations of both PGP9.5-immunoreactive and PGP9.5-negative ENCCs exhibited spontaneous $\left[\mathrm{Ca}^{2+}\right]_{\mathrm{i}}$ transients. The spontaneously active PGP9.5-negative ENCCs may be cells that were just

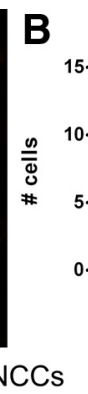

PGP9.5-positive ENCCs

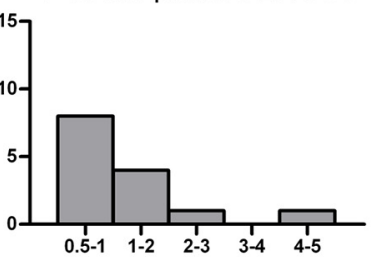

Frequency of spontaneous activity (transients per minute)

D PGP9.5-negative ENCCs
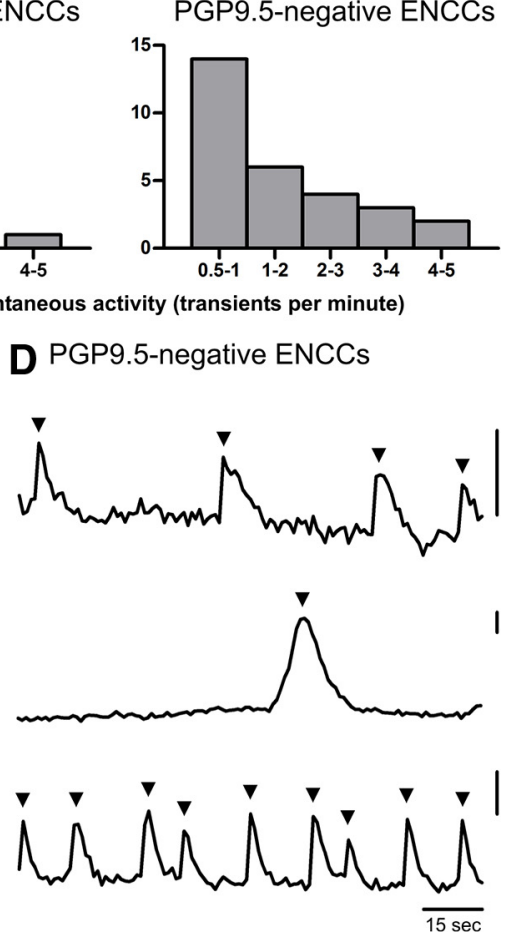

Figure 6. Spontaneous $\left[\mathrm{Ca}^{2+}\right]_{\mathrm{i}}$ transients in E11.5 ENCCS. A, Fluorescence micrograph of E11.5 cultures stained against GFP/ 作

beginning to differentiate into neurons, but whether they could also differentiate into glial cells is yet to be determined. Trunklevel neural crest cells isolated from E9.5-E10 mice have been shown to exhibit spontaneous $\left[\mathrm{Ca}^{2+}\right]_{\mathrm{i}}$ transients after $1-3 \mathrm{~d}$ in culture, and only cells with spontaneous activity differentiated into neurons (Carey and Matsumoto, 1999). Further, neural crest cells that emigrate from explants of quail neural tube express nicotinic receptors and display ionic currents after several days in culture (Howard et al., 1995). We found that spontaneous action potentials are present in E12.5 enteric neurons using whole-cell patch-clamp electrophysiology. Spontaneous activity in PGP9.5positive neurons probably influences differentiation of their neurotransmitter phenotype. We have previously shown that inhibition of endogenous activity using TTX delays differentiation of nitrergic neurons in cultured explants of E11.5 gut (Hao et al., 2010). Similarly, in the developing spinal cord of Xenopus laevis, inhibition of $\left[\mathrm{Ca}^{2+}\right]_{\mathrm{i}}$ spikes in neurons retards differentiation of inhibitory neurons (Borodinsky et al., 2004).

We further characterized the activity in embryonic enteric neurons induced by electrical stimulation. Neural activity at all embryonic ages, including E11.5, was dependent on voltagegated $\mathrm{Na}^{+}$channels. $\left[\mathrm{Ca}^{2+}\right]_{\mathrm{i}}$ transients induced by electrical stimulation were sensitive to TTX, suggesting that they were driven by action potentials and were not a form of $\mathrm{Ca}^{2+}$-driven excitability. Action potentials recorded from E12.5 neurons were quite similar in shape to those recorded from adult murine enteric neurons (Mao et al., 2006). This suggests a mature form of $\mathrm{Na}^{+}$-dependent activity at very early developmental ages. However, the amplitude of E12.5 action potentials were much smaller than those of the adult (Mao et al., 2006). We also observed an increase in EFS-evoked $\left[\mathrm{Ca}^{2+}\right]_{\mathrm{i}}$ transient amplitudes from E11.5 
A

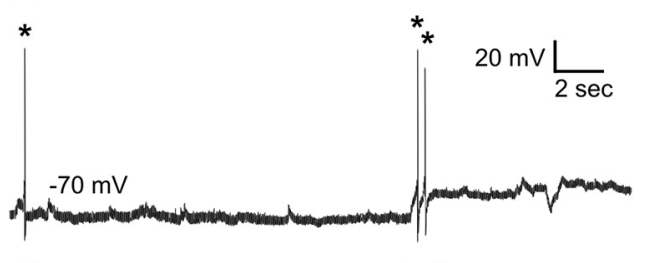

$\mathrm{H}$

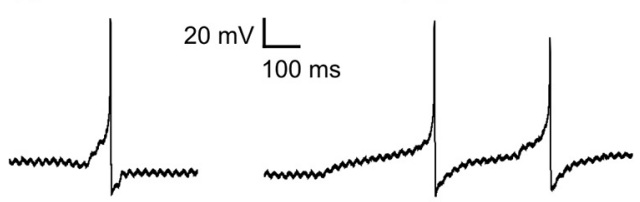

B
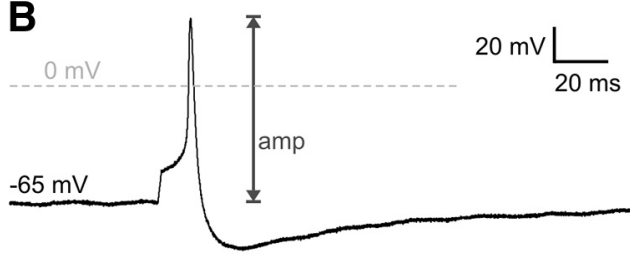

\begin{tabular}{ll} 
几 \\
\hline $\mathrm{pA}$ & $+70 \mathrm{pA}$
\end{tabular}

Figure 7. Whole-cell patch-clamp recordings of E12.5 enteric neurons. $\boldsymbol{A}$, Spontaneous action potentials at resting membrane potential (asterisk). Close-ups of the action potentials (bars) shown below. $\boldsymbol{B}$, Action potentials (upper trace) were evoked using $1 \mathrm{~ms}$ depolarizing current steps (lower trace).

to E18.5. The increase in $\left[\mathrm{Ca}^{2+}\right]_{\mathrm{i}}$ response also appears to mature along the rostral-caudal axis of the gut as the amplitude of responses in neurons from E15.5 and E18.5 duodenum were higher than those from colon at the same ages. This is not unexpected as the ENCCs colonize the duodenum several days before the colon (Kapur et al., 1992). The increases in $\left[\mathrm{Ca}^{2+}\right]_{\mathrm{i}}$ transient amplitude and action potential amplitude between E11.5 and E18.5 probably result from increased ion channel expression and/or changes in the ion channel properties. At embryonic ages, action potential-firing neurons have very high input resistances, indicating that their expression of ion channels is very low. In other parts of the nervous system where embryonic neurons exhibit mature forms of electrical activity, an increase in the density of these currents also occurs during development (Bader et al., 1983; Krieger and Sears, 1988; Rothe et al., 1999; Lechner et al., 2009).

Pharmacological studies showed that voltage-gated $\mathrm{Ca}^{2+}$ channels play important roles, although they are not completely responsible for the generation of $\left[\mathrm{Ca}^{2+}\right]_{i}$ transients. In the adult ENS, N-, P/Q-, L- and R-type $\mathrm{Ca}^{2+}$ currents have been recorded, mostly from guinea pig myenteric neurons (Kirchgessner and Liu, 1999; Starodub and Wood, 1999; Reis et al., 2000; Bian and Galligan, 2007). In the current study, N-type voltage-gated $\mathrm{Ca}^{2+}$ channels were responsible for most of the $\mathrm{Ca}^{2+}$ entry at all embryonic ages. P/Q-, T-, R- and L-type $\mathrm{Ca}^{2+}$ channels contributed to the $\mathrm{Ca}^{2+}$ influx to a much smaller extent and their contributions varied between ages. This may indicate transient involvement of some channel subtypes. There may also be $\mathrm{Ca}^{2+}$-dependent $\mathrm{Ca}^{2+}$ release from intracellular stores that amplifies the initial extracellular influx of $\mathrm{Ca}^{2+}$, and thus VGCC contribution cannot be directly measured from the amplitude of the $\left[\mathrm{Ca}^{2+}\right]_{i}$ peak. Although the initiation of EFS-induced $\left[\mathrm{Ca}^{2+}\right]_{\mathrm{i}}$ transients was completely dependent on the influx of extracellular $\mathrm{Ca}^{2+}$ ions, as they were abolished in $\mathrm{Ca}^{2+}$-free bath solution, the transients were not completely eliminated by a cocktail of antagonists to block all five types of VGCCs, implying involvement of other $\mathrm{Ca}^{2+}$-permeable channels. Members of the transient receptor potential (TRP) channel family are likely candidates as most of them conduct $\mathrm{Ca}^{2+}$ and some are voltage dependent (Talavera et al., 2008). Several TRP channels are expressed in the mature ENS (Boesmans et al., 2011) and also in parts of the developing mammalian nervous system that are also of neural crest origin, including embryonic dorsal root ganglion neurons (Tamura et al., 2005; Elg et al., 2007). In particular, the role of canonical TRP (TRPC) channels, which mediate guidance of growth cones and survival of neurons in response to chemical cues such as neurotrophins (Talavera et al., 2008), is worth pursuing.

In the developing mouse ENS, the differentiation of neurotransmitter subtype starts at early stages, beginning from E11, and a recent study showed expression of multiple serotonin receptors by ENCCs isolated from E16 mouse gut (Li et al., 2011). Different classes of enteric neurons exit the cell cycle and exhibit neurotransmitter or synthetic enzyme expression at different developmental ages (for review, see Hao and Young, 2009). In the current study, we demonstrated the presence of functional nicotinic receptors in E11.5 cultures. Surprisingly the $\left[\mathrm{Ca}^{2+}\right]_{i}$ amplitude displays a bell-shaped dependency with age, which could be explained by changes in nicotinic subunit composition during maturation, as different subunits have different abilities to conduct $\mathrm{Ca}^{2+}$. Receptors for ATP were also expressed early on in E11.5 cultures, followed by the appearance of receptors to 5-HT in E12.5 cultures, and responses to CGRP in a very small number of E18.5 duodenum neurons. The appearance of CGRP and nicotinic receptors coincides with the time of the first detection of CGRP at E17 (Branchek and Gershon, 1989) and cholinergic neurons at E11 (Rothman and Gershon, 1982) respectively. However, not all neurotransmitter receptor expression appears to be coordinated with synthesis of the corresponding neurotransmitter as we could not detect functional receptors to substance $\mathrm{P}$ at any embryonic age, despite the presence of substance P at E14.5 (Rothman et al., 1984). Furthermore, there is no obvious correlation between the time of cell cycle exit for different types of enteric neurons (Pham et al., 1991) and the first expression of a neurotransmitter phenotype or receptors to neurotransmitters.

The neurites of cultured E11.5 neurons showed EFS-evoked $\left[\mathrm{Ca}^{2+}\right]_{\mathrm{i}}$ transients and synaptophysin staining, further suggesting the possibility of synaptic transmission between cells. Previous studies found that inhibition of synaptic release using clostridial toxins also perturbs ENCC migration (Vohra et al., 2006; Hao et al., 2010). Also, mutant mice lacking the norepinephrine transporter ( $\mathrm{Li}$ et al., 2010) or neuronal serotonin ( $\mathrm{Li}$ et al., 2011) have reduced numbers of enteric neurons, indicating roles for these neurotransmitters in enteric neuron differentiation and/or survival. Exogenous application of 5-HT and depolarization of neurons using EFS, high- $\mathrm{K}^{+}$or the voltage-gated $\mathrm{Na}^{+}$channel agonist veratridine in long term cultures of embryonic enteric neurons in vitro influences neuron phenotype differentiation (Fiorica-Howells et al., 2000; Chevalier et al., 2008). Combined, these data are consistent with a role for endogenous neurotransmitter signaling in ENS development. However, not all neurotransmitters appear to be involved, as inhibition of nitric oxide synthase activity did not affect ENCC migration or differentiation (Hao et al., 2010).

In this study, we provide direct evidence for the presence of neural activity in E11.5-E12.5 enteric neurons following shortterm culture. Along with the spinal cord, hindbrain and dorsal root ganglia (Spitzer and Baccaglini, 1976; Gust et al., 2003; Lech- 
ner et al., 2009), the ENS appears to be one of the earliest parts of the nervous system to exhibit electrical activity. Endogenous neural activity has been shown to influence early events in ENS development including ENCC migration and differentiation (Vohra et al., 2006; Hao et al., 2010; Li et al., 2010). Our study raises the possibility that neural activity also guides later developmental processes, such as axon pathfinding and synaptogenesis, and the development of functioning neural circuits in the ENS.

\section{Notes}

Supplemental material for this article is available at https://videolab.avnet. kuleuven.be/video/?id $=272 \mathrm{c} 16 f 45 \mathrm{a} 561 \mathrm{~cd} 3 \mathrm{ba} 509200 \mathrm{e} 835 \mathrm{ceb} 0 \&$ autostart $=$ false\&height $=388 \&$ width $=640$. Movie 1 : Electrical field stimulation (EFS) of E11.5 ENCCs. YFP ${ }^{+}$ENCCs from E11.5 cultured overnight loaded with Fluo-4AM (see Materials and Methods) responded to EFS with increases in their $\left[\mathrm{Ca}^{2+}\right]_{\mathrm{i}}$. A total of $30 \mathrm{~s}$ of a $60 \mathrm{~s}$ recording is displayed, with $\mathrm{EFS}(20 \mathrm{~Hz})$ applied at $t=15 \mathrm{~s}$ for $2 \mathrm{~s}$. An increase in $\left[\mathrm{Ca}^{2+}\right]_{\mathrm{i}}$ was detected in the cell bodies (yellow arrows) and neurites (red arrows) of several cells. Scale bar, 20 $\mu \mathrm{m}$. This material has not been peer reviewed.

\section{References}

Anderson RB, Stewart AL, Young HM (2006) Phenotypes of neural-crestderived cells in vagal and sacral pathways. Cell Tissue Res 323:11-25.

Bader CR, Bertrand D, Kato AC (1983) Membrane currents in a developing parasympathetic ganglion. Dev Biol 98:515-519.

Baetge G, Gershon MD (1989) Transient catecholaminergic (TC) cells in the vagus nerves and bowel of fetal mice: relationship to the development of enteric neurons. Dev Biol 132:189-211.

Ben-Ari Y (2008) Neuro-archaeology: pre-symptomatic architecture and signature of neurological disorders. Trends Neurosci 31:626-636.

Ben-Ari Y, Spitzer NC (2010) Phenotypic checkpoints regulate neuronal development. Trends Neurosci 33:485-492.

Ben-Ari Y, Cherubini E, Corradetti R, Gaiarsa JL (1989) Giant synaptic potentials in immature rat CA3 hippocampal-neurons. J Physiol 416:303-325.

Bian X, Galligan JJ (2007) $\mathrm{a}_{2}$-Adrenoceptors couple to inhibition of R-type calcium currents in myenteric neurons. Neurogastroenterol Motil 19:845-855.

Bian X, Zhou X, Galligan JJ (2004) R-type calcium channels in myenteric neurons of guinea pig small intestine. Am J Physiol Gastrointest Liver Physiol 287:G134-G142.

Boesmans W, Gomes P, Janssens J, Tack J, Vanden Berghe P (2008) Brainderived neurotrophic factor amplifies neurotransmitter responses and promotes synaptic communication in the enteric nervous system. Gut 57:314-322.

Boesmans W, Ameloot K, van den Abbeel V, Tack J, Vanden Berghe P (2009) Cannabinoid receptor 1 signalling dampens activity and mitochondrial transport in networks of enteric neurones. Neurogastroenterol Motil 21:958-e77.

Boesmans W, Owsianik G, Tack J, Voets T, Vanden Berghe P (2011) TRP channels in neurogastroenterology: opportunities for therapeutic intervention. Br J Pharmacol 162:18-37.

Bornstein JC, Costa M, Grider JR (2004) Enteric motor and interneuronal circuits controlling motility. Neurogastroenterol Motil 16 [Suppl 1]:34-38.

Borodinsky LN, Root CM, Cronin JA, Sann SB, Gu X, Spitzer NC (2004) Activity-dependent homeostatic specification of transmitter expression in embryonic neurons. Nature 429:523-530.

Branchek TA, Gershon MD (1989) Time course of expression of neuropeptide $\mathrm{Y}$, calcitonin gene-related peptide, and NADPH diaphorase activity in neurons of the developing murine bowel and the appearance of 5 -hydroxytryptamine in mucosal enterochromaffin cells. J Comp Neurol 285:262-273.

Burns AJ, Roberts RR, Bornstein JC, Young HM (2009) Development of the enteric nervous system and its role in intestinal motility during fetal and early postnatal stages. Semin Pediatr Surg 18:196-205.

Carey MB, Matsumoto SG (1999) Spontaneous calcium transients are required for neuronal differentiation of murine neural crest. Dev Biol 215:298-313.

Cassiman D, Barlow A, Vander Borght S, Libbrecht L, Pachnis V (2006)
Hepatic stellate cells do not derive from the neural crest. J Hepatol 44:1098-1104.

Chevalier J, Derkinderen P, Gomes P, Thinard R, Naveilhan P, Vanden Berghe P, Neunlist M (2008) Activity-dependent regulation of tyrosine hydroxylase expression in the enteric nervous system. J Physiol 586:1963-1975.

Chitkara DK, van Tilburg MA, Blois-Martin N, Whitehead WE (2008) Early life risk factors that contribute to Irritable Bowel Syndrome in adults: a systematic review. Am J Gastroenterol 103:765-774.

Druckenbrod NR, Epstein ML (2005) The pattern of neural crest advance in the cecum and colon. Dev Biol 287:125-133.

Elg S, Marmigere F, Mattsson JP, Ernfors P (2007) Cellular subtype distribution and developmental regulation a TRPC channel members in the mouse dorsal root ganglion. J Comp Neurol 503:35-46.

Eliot LS, Johnston D (1994) Multiple components of calcium current in acutely dissociated dentate gyrus granule neurons. J Neurophysiol 72:762-777.

Fiorica-Howells E, Maroteaux L, Gershon MD (2000) Serotonin and the $5-\mathrm{HT}_{2 \mathrm{~B}}$ receptor in the development of enteric neurons. J Neurosci 20:294-305.

Furness JB (2006) The enteric nervous system. Oxford, UK: Blackwell.

Galligan JJ (2002) Ligand-gated ion channels in the enteric nervous system. Neurogastroenterol Motil 14:611-623.

Gershon MD (2010) Developmental determinants of the independence and complexity of the enteric nervous system. Trends Neurosci 33:446-456.

Gomes P, Chevalier J, Boesmans W, Roosen L, van den Abbeel V, Neunlist M, Tack J, Vanden Berghe P (2009) ATP-dependent paracrine communication between enteric neurons and glia in a primary cell culture derived from embryonic mice. Neurogastroenterol Motil 21:870-e62.

Gu X, Spitzer NC (1995) Distinct aspects of neuronal differentiation encoded by frequency of spontaneous $\mathrm{Ca}^{2+}$ transients. Nature 375:784-787.

Gust J, Wright JJ, Pratt EB, Bosma MM (2003) Development of synchronized activity of cranial motor neurons in the segmented embryonic mouse hindbrain. J Physiol 550:123-133.

Hao MM, Young HM (2009) Development of enteric neuron diversity. J Cell Mol Med 13:1193-1210.

Hao MM, Moore RE, Roberts RR, Nguyen T, Furness JB, Anderson RB, Young HM (2010) The role of neural activity in the migration and differentiation of enteric neuron precursors. Neurogastroenterol Motil 22:e127-e137.

Holliday J, Spitzer NC (1990) Spontaneous calcium influx and its roles in differentiation of spinal neurons in culture. Dev Biol 141:13-23.

Howard MJ, Gershon MD, Margiotta JF (1995) Expression of nicotinic acetylcholine receptors and subunit mRNA transcripts in cultures of neural crest cells. Dev Biol 170:479-495.

Kapur RP, Yost C, Palmiter RD (1992) A transgenic model for studying development of the enteric nervous system in normal and aganglionic mice. Development 116:167-175.

Kirchgessner AL, Liu MT (1999) Differential localization of $\mathrm{Ca}^{2+}$ channel $a_{1}$ subunits in the enteric nervous system: Presence of $a_{1 B}$ channel-like immunoreactivity in intrinsic primary afferent neurons. J Comp Neurol 409:85-104

Krieger C, Sears TA (1988) The development of voltage-dependent conductances in murine spinal-cord neurons in culture. Can J Physiol Pharmacol 66:1328-1336.

Laranjeira C, Pachnis V (2009) Enteric nervous system development: Recent progress and future challenges. Auton Neurosci 151:61-69.

Lechner SG, Frenzel H, Wang R, Lewin GR (2009) Developmental waves of mechanosensitivity acquisition in sensory neuron subtypes during embryonic development. EMBO J 28:1479-1491.

Le Douarin NM, Teillet MA (1973) The migration of neural crest cells to the wall of the digestive tract in avian embryo. J Embryol Exp Morphol 30:31-48.

Li Z, Caron MG, Blakely RD, Margolis KG, Gershon MD (2010) Dependence of serotonergic and other nonadrenergic enteric neurons on norepinephrine transporter expression. J Neurosci 30:16730-16740.

Li Z, Chalazonitis A, Huang YY, Mann JJ, Margolis KG, Yang QM, Kim DO, Côté F, Mallet J, Gershon MD (2011) Essential roles of enteric neuronal serotonin in gastrointestinal motility and the development/survival of enteric dopaminergic neurons. J Neurosci 31:8998-9009. 
Magistrettri J, Mantegazza M, Guatteo E, Wanke E (1996) Action potentials recorded with patch-clamp amplifiers: are they genuine? Trends Neurosci 19:530-534.

Mao Y, Wang B, Kunze W (2006) Characterization of myenteric sensory neurons in the mouse small intestine. J Neurophysiol 96:998-1010.

Milner LD, Landmesser LT (1999) Cholinergic and GABAergic inputs drive patterned spontaneous motoneuron activity before target contact. J Neurosci 19:3007-3022.

Moody WJ, Bosma MM (2005) Ion Channel Development, Spontaneous Activity, and Activity-Dependent Development in Nerve and Muscle Cells. Physiol Rev 85:883-941.

Pham TD, Gershon MD, Rothman TP (1991) Time of origin of neurons in the murine enteric nervous system: sequence in relation to phenotype. J Comp Neurol 314:789-798.

Reis HJ, Massensini AR, Prado MA, Gomez RS, Gomez MV, Romano-Silva MA (2000) Calcium channels coupled to depolarization-evoked glutamate release in the myenteric plexus of guinea-pig ileum. Neuroscience 101:237-242.

Roberts RR, Ellis M, Gwynne RM, Bergner AJ, Lewis MD, Beckett EA, Bornstein JC, Young HM (2010) The first intestinal motility patterns in fetal mice are not mediated by neurons or interstitial cells of Cajal. J Physiol 588:1153-1169.

Rothe T, Jüttner R, Bähring R, Grantyn R (1999) Ion conductances related to development of repetitive firing in mouse retinal ganglion neurons in situ. J Neurobiol 38:191-206.

Rothman TP, Gershon MD (1982) Phenotypic expression in the developing murine enteric nervous system. J Neurosci 2:381-393.

Rothman TP, Nilaver G, Gershon MD (1984) Colonization of the developing murine enteric nervous system and subsequent phenotypic ex- pression by the precursors of peptidergic neurons. J Comp Neurol 225:13-23.

Spitzer NC (2006) Electrical activity in early neuronal development. Nature 444:707-712.

Spitzer NC, Baccaglini PI (1976) Development of the action potential in embryo amphibian neurons in vivo. Brain Res 107:610-616.

Starodub AM, Wood JD (1999) Selectivity of w-CgTx-MVIIC toxin from Conus magus on calcium currents in enteric neurons. Life Sci 64:PL305-PL310.

Talavera K, Nilius B, Voets T (2008) Neuronal TRP channels: thermometers, pathfinders and life-savers. Trends Neurosci 31:287-295.

Tamura S, Morikawa Y, Senba E (2005) TRPV2, a capsaicin receptor homologue, is expressed predominantly in the neurotrophin-3-dependent subpopulation of primary sensory neurons. Neuroscience 130:223-228.

Vanden Berghe P, Tack J, Boesmans W (2008) Highlighting synaptic communication in the enteric nervous system. Gastroenterology 135:20-23.

Vohra BP, Tsuji K, Nagashimada M, Uesaka T, Wind D, Fu M, Armon J, Enomoto H, Heuckeroth RO (2006) Differential gene expression and functional analysis implicate novel mechanisms in enteric nervous system precursor migration and neuritogenesis. Dev Biol 298:259-271.

Wong RO, Chernjavsky A, Smith SJ, Shatz CJ (1995) Early functional neural networks in the developing retina. Nature 374:716-718.

Young HM (2008) Functional development of the enteric nervous systemfrom migration to motility. Neurogastroenterol Motil 20:20-31.

Young HM, Newgreen D (2001) Enteric neural crest-derived cells: Origin, identification, migration, and differentiation. Anat Rec 262:1-15.

Young HM, Ciampoli D, Hsuan J, Canty AJ (1999) Expression of ret-, p75 ${ }^{\text {NTR }}$-, Phox2a-, Phox2b-, and tyrosine hydroxylase-immunoreactivity by undifferentiated neural crest-derived cells and different classes of enteric neurons in the embryonic mouse gut. Dev Dyn 216:137-152. 